\title{
PEMANFAAT LIMBAH ENCENG GONDOK BERBASIS PELATIHAN KONTINUM RELATIONSHIP DI DESA KEMLAGI LOR KECAMATAN TURI KABUPATEN LAMONGAN
}

\author{
*( Evi Fitrotin Naji'ah ${ }^{1}$, Nurul Badriyah ${ }^{2}$ \\ Prodi Manajemen, Fakultas Ekonomi, Universitas Islam Lamongan \\ $\mathrm{Jl}$. Veteran No.53A Lamongan \\ Telp. ( 0322 ) 324706, Faks. ( 0322 ) 324706 \\ Email :jpim.unisla@gmail.com
}

\begin{abstract}
ABSTRAK
Tanaman enceng gondok (Elchornia Ccrassipes) merupakan tumbuhan air yang tumbuh dirawa - rawa., danau dan waduk. Pertumbuhannya sangat cepat 3\% per hari mampu menutupi seluruh permukaan sungai, setiap kepala putik dapat menghasilkan sekitar 500 bakal biji atau 5000 biji setiap tangkai bunga, sehingga enceng gondok dapat berkembang biak dengan cepat Tanaman enceng gondok berdampak pada tersumbatnya aliran sungai menuju hulu, sehingga banjir lebih cepat menggenangi jalan dan persawahan warga. Berdasarkan data BPS Kabupaten Lamongan akibat dari bencana banjir kerugian yang diderita sebesar 1, 386 milyard persatu kali bencana. Pelatihan kontinum relationship dilaksanakan dengan mengumpulkan kelompok karang taruna dan dilakukan pndampingan secara komprehensip sampai mampu membuat produk sendiri. Perwujudan pelatihan kontinum relationship dibutuhkan sebagai upaya perbaikan dan pemberdayaan siklus bisnis yang dirancang harus berlanjut (Sustainable), hasil dari pendampingan ini adalah Pemberdayaan sistem kontinum relationship menguntungkan pihak mitra karena sangat menguntungkan mitra sebagai usaha pemula. Aspek marketing yang ditakutkan oleh pengusaha pemula dapat diatasi ketika mitra kedua sebagai pemateri sekaligus sebagai market dengan gandeng renteng sesama pengusaha. Aspek manajemen selanjutnya dilakukan guna menunjang keberlanjutan program kearah kesuksesan usaha yang sedang dirintis.
\end{abstract}

Kata Kunci: Pemanfaatan, Limbah enceng gondok, Pelatihan kontinum relationship

\section{PENDAHULUAN}

Indonesia kaya akan sumberdaya alam baik energy, tanaman atau tambang, kekayaan alam yang melimpah rua kadang tidak berfikir untuk dimanfaatkan bahkan justru berakibat bencana pada daerah tertentu. Desa Kemlagi lor kecamatan Turi kabupaten Lamonga merupakan desa yang dilewati hamparan sungai bengawan jero (Bono rowo). Kondisi Geografis wilayah yang memiliki perairan luas dan panjang ini sering terjadi banjir, apabila ada hujan deras dan akibat meluapnya sungai bengawan jero.

Kesadaran masyarakat terhadap pengelolaan sungai belum optimal. Tanaman enceng gondok tumbuh subur dihamparan sungai yang panjang dan luas berdampak pada tersumbatnya aliran sungai menuju hulu, sehingga banjir lebih cepat menggenangi jalan dan persawahan warga. Berdasarkan data BPS Kabupaten Lamongan yang terhimpun, desa Kemlagi lor tiap tahun menjadi 
langganan banjir hingga ketinggian mencapai $80 \mathrm{~cm}$. Akibat dari bencana banjir tersebut kerugian yang diderita sebesar 1, 386 milyard persatu kali bencana. Kerugian tersebut meliputi kerusakan rumah penduduk, harta benda, ternak dan pertanian.

Penduduk desa Kemlagi lor berjumlah 332 kepala keluarga, secara umum mata pencaharian teridentifikasi kedalam beberapa sektor yaitu pertanian $76,7 \%$, perdagangan $3,09 \%$ industry 0 , $54 \%$ dan sector lain $0,90 \%$ dengan tingkat pengahsilan rata rata $\mathrm{Rp}$. 1.500.000 per bulan. Melihat data tersebut angka pengangguran di desa Kemlagi lor cukup rendah. Kelembagaan memuaskan dan berjalan sesuai fungsinya. Karang taruna yang terbentuk mulai tahun 2014 dengan ketua saudara Wenny memiliki program yang belum menyentuh pemanfaatan sumberdaya alam sebagai nilai kearifan lokal secara optimal.

Tanaman enceng gondok (Elchornia Ccrassipes) merupakan tumbuhan air yang tumbuh dirawa - rawa., danau dan waduk. Pertumbuhannya sangat cepat $3 \%$ per hari mampu menutupi seluruh permukaan sungai, setiap kepala putik dapat menghasilkan sekitar 500 bakal biji atau 5000 biji setiap tangkai bunga, sehingga enceng gondok dapat berkembang biak dengan dua cara yaitu dengan tunas dan biji. Jenis tanaman enceng gondok ini mudah layu dan mati apabila sudah dangkat kedaratan dan terkenah sinar matahari.

Melihat analisis situasi dan permasalahan bencana banjir yang dialami desa Kemlagi lor dan aktivitas kegiatan karang taruna masyarakat desa Kemlagi lor. Program dengan konsep ekonomi kreatif ini bertujuan untuk memprioritaskan pembersihan tanaman enceng gondok dari hilir sungai yang panjang dan luas kemudian dimanfaatkan menjadi produk yang bernilai jual tinggi.

Pemanfaatan tanaman enceng gondok menjadi produk telah banyak dilakukan diberbagai daerah, sedangkan di Kabupaten Lamongan sendiri ada perusahaan handycraft yang memanfaatkan daun mendong dan pandan sebagai bahan produk kerajinan. Dengan adanya bahan enceng gondok ini kemungkinan dapat dijadikan produk pengembangan usaha tersebut. Oleh karena itu program pelatihan kontinum relationship atau pelatihan dengan pendampingan berkelanjutan dapat dijadikan solusi bersama mitra untuk mengurangi banjir dan pemanfaatan sumberdaya alam enceng gondok serta pemberdayaan pemuda - pemudi karang taruna.

Raimond, (2015) berpendapat bahwa masyarakat ekonomi kreatif adalah usaha yang dilakukan oleh masyarakat setempat untuk peningkatan penghasilan jati dirinya. Sedangkan Grandi (2015); Gaglin, et al (2014) menyebutkan bahwa hasil kreatifitas masyarakat setempat dengan memanfaatkan kearifan lokal bentuk usaha peningkatan pendapatan masyarakat setempat. Pemuda - pemudi yang tergabung dalam karang taruna belum mengetahui bahwa enceng gondok dapat dimanfaatkan untuk kerajinan tangan (handycraft) dan bernilai jual tinggi yang dapat menambah penghasilan bagi penduduk setempat. Pelatihan kontinum reletionship ini melibatkan 2 (dua) mitra yang berbeda, mitra pertama yaitu muda - mudi yang tergabung dalam karang taruna di berikan pelatihan cara pengolahan dan pemanfaatan tanaman enceng gondok sebagai produk kerajinan handycraft dan solusi mengurangi genangan air / banjir. Mitra kedua adalah UMKM handycraft yang ada di Kabupaten 
Lamongan sebagai obyek pengalaman mengolah bahan dari alamiah dan mitra pemasaran untuk pengembangan produk yang telah ada. Pelatihan kontinum relationship sebagaimana pendapat Aronson et al 2014, menggambarkan kondisi pemberdayaan masyarakat secara komprehensip mulai dari proses produksi pemanfaatan limbah enceng gondok sampai mengakomodir strategi marketing yaitu bekerjasama dengan UMKM yang maju serta memberikan jalan untuk dibina oleh dinas industri dan perdagangan Kabupaten Lamongan.

Dalam pelatihan kontinum relationship ada tiga komponen yang harus dilalui. Ketiga komponen itu adalah masukan (input), proses dan keluaran ( Output) seperti pada gambar dibawah ini :

\begin{tabular}{|c|c|c|}
\hline $\begin{array}{c}\text { Input } \\
\text { Introductio } \\
n, \\
\text { Pengenalan } \\
\text { manfaat } \\
\text { enceng } \\
\text { gondok } \\
\text { yang } \\
\text { bernilai jual } \\
\text { tinggi }\end{array}$ & $\begin{array}{l}\text { Proses } \\
\text { Penda } \\
\text { mping } \\
\text { an } \\
\text { pelatih } \\
\text { an } \\
\text { kontin } \\
\text { um } \\
\text { Relatio } \\
\text { nship } \\
\text { tinggi }\end{array}$ & $\begin{array}{c}\text { Output } \\
\text { Produk kerajinan } \\
\text { berbahan enceng } \\
\text { gondok } \\
\text { Pemasaran } \\
\text { dengan mitra } \\
\text { kedua }\end{array}$ \\
\hline
\end{tabular}

Gambar 2. Diagram alur proses pelatihan kontinum relationship Sumber Aronson, 2014

Pelatihan kontinum relationship dilaksanakan dengan mengumpulkan pemuda - pemudi yang tergabung dalam kelompok karang taruna dan dilakukan sosialisasi program, yang kemudian dilakukan pndampingan secara komprehensip sampai mampu membuat produk sendiri, dan pada akhirnya dibantu proses pemasaran oleh mitra kedua yaitu $\mathrm{R}$ \& D craft yang ada di Kabupaten Lmaongan. Perwujudan pelatihan kontinum relationship dibutuhkan sebagai upaya perbaikan dan pemberdayaan siklus bisnis yang dirancang harus berlanjut (Sustainable), Zahrowitz (2014). Sistem pelatihan, pemberdayaan dan pendampingan merupakan formulasi tumbuhnya industri masyarakat di pasar lokal dan internasional, Bet et al (2014)

\section{METODE PENELITIAN}

\section{a). Pelatihan}

\section{Masukan (Input)}

Masukan adalah proses perkenalan atau identifikasi dan sosialisasi program yang akan dilaksanakan pada obyek pendampingan yaitu pemuda - pemudi karang taruna desa Kemlagi lor

a). Sosialisasi Program

Kontinum relationship digunakan untuk mengidentifikasi kategori pelatihan secara khusus dan relevan dengan kebutuhan peserta pelatihan , diperlukan tinjauan media dan teknologi yang tepat untuk membina peserta pelatihan secara komprehensif dari hulu hingga ke hilir dengan prespektif yang tepat.

Spesifikasi pendampingan pelatihan kontinum relationship.

1. Konten, memiliki metode pelatihan sesuai dengan karakteristik dan keadaan peserta

2. Konteks, menggunakan kombinasi pelatihan, pendampingan dan pemberdayaan, sehingga menghasilkan nilai yang dapat meningkatkan perekonomian masyarakat setempat.

b). Metode Pelatihan

1. Tukar pendapat yaitu proses 
kreatifitas untuk menghasilkan ide yang berkaitan dengan pengalaman, hal ini dimungkinkan pemuda - pemudi karang taruna desa kemlagi lor sudah ada yang berpengalaman mengelolah bahan enceng gondok.

2. Sumbang saran proses berbagi pengalaman dengan peserta sebagai sumber belajar dengan tujuan outcome lebih kreasi dan inovasi yang layak dikanca persaingan dunia usaha.

3. Ceramah, sumber inspirasi dan wawasan dalam bekreasi memanfaatkan kearifan local.

4. Menciptakan pengusaha yang memiliki kompetensi, kemampuan produksi dan menarik daya saing konsumen.

\section{Proses}

Pendampingan kontinum relationship dengan tahapan:

1. Pembersihan aliran sungai dari enceng gondok untuk bahan baku, dengan kegiatan:

a) Melakukan kerja bakti dengan warga untuk mencari bahan baku berupa tanaman enceng gondok dari hilir sungai.

b) Melakukan pemilihan bahan enceng gondok yang berkualitas, dengan memisahkan daun dan tangkai. Tangkai yang bagus dipisahkan dan daunnya dapat dimanfaatkan untuk kerajinan yang lain.

Proses Pembuatan Kerajinan Enceng Gondok

a) Untuk mempersiapkan eceng gondok menjadi bahan baku anyaman diperlukan beberapa bahan penunjang. di antaranya : air bersih.Yang digunakan untuk membersihkan eceng gondok dari kotoran yang menempel.

b) Bagian yang digunakan sebagai bahan kerajinan adalah tangkai daunnya, maka bagian yang lain harus dibuang. Setelah bagian-bagian yang tidak dibutuhkan dibuang, tangkai eceng gondok kemudian bisa segera dicuci dan dibilas hingga benar-benar bersih.

c) Setelah tangkai eceng gondok bersih, selanjutnya bisa dijemur dengan sesekali dibalik hingga tangkai benar-benar kering. Waktu penjemuran kurang lebih selama 6 hari atau tergantung pada ketebalan tangkai dan cuaca (ada tidaknya sinar matahari).

d) Apabila tangkai eceng gondok telah kering, selanjutnya adalah pembelahan. Adakalanya karena tuntutan ketentuan dalam desain anyamannya, eceng gondok kering perlu dibelah menjadi beberapa bagian.

e) Eceng gondok yang telah dijemur dan dibelah kemudian dianyam untuk mendapat lembaran-lembaran eceng anyaman eceng gondok.

\section{Keluaran (Output)}

Keluaran adalah segala sesuatu yang dihasilkan dari proses produksi. Dalam proses produksi pelatihan kontinum relationship menghasilkan kerajinan tangan (handycraft). Di Desa Keomlagi lor Kecamatan Turi Kabupaten Lamongan adalah sebagai berikut:

Produk Hasil akhir pengolahan limbah 
enceng gondok adalah kerajinan tangan baik berupa tas, sepatu, tempat tisu atau lainnya dengan tujuan memiliki nilai jual tinggi untuk meningkatkan ekonomi kreatif masyarakat desa Kemlagi Lor Kecamatan Turi Kabupaten Lamongan.
a. Justifikasi
Tim
Penerapan

Pemberdayaan bagi masyarakat bersama mitra dalam menentukan permasalahan.

Justifikasi Tim Penerapan

Pemberdayaan bagi masyarakat bersama mitra dalam menentukan permasalahan, dilihat pada table berikut ini:

Tabel 1. Permasalahan prioritas dan justifikasi

\begin{tabular}{|c|c|c|}
\hline Permasalahan Prioritas & Justifikasi & $\begin{array}{l}\text { Jumlah Anggota Karang } \\
\text { Taruna Yang Dilibatkan }\end{array}$ \\
\hline \multirow{4}{*}{$\begin{array}{l}\text { Rendahnya pengetahuan } \\
\text { pemuda - pemudi karang } \\
\text { taruna tentang limbah } \\
\text { enceng gondok }\end{array}$} & $\begin{array}{l}\text { a. Soialisasi tentang pengolahan limbah enceng } \\
\text { gondok untuk kerajinan tangan. }\end{array}$ & 40 \\
\hline & $\begin{array}{l}\text { b. Sosialisasi jenis bahan enceng gondok yang } \\
\text { dapatdimanfaatkan sebagai bahan baku kerajinan } \\
\text { tangan. }\end{array}$ & 40 \\
\hline & $\begin{array}{l}\text { c. Penelurusan aksi dengan pemetaan alternative } \\
\text { pemecahan }\end{array}$ & 40 \\
\hline & d. Membuat rencana aksi & 40 \\
\hline \multirow{3}{*}{\begin{tabular}{lrr} 
Tidak & \multicolumn{2}{c}{ mengetahui } \\
kulaitas produksi yang \\
layak dijual dan daya \\
saing tinggi
\end{tabular}} & $\begin{array}{l}\text { a. Pemilihan tanaman enceng gondok yang layak } \\
\text { digunakan bahan baku dari akar hingga daun }\end{array}$ & 40 \\
\hline & b. Membuat metode, model, pola olahan & 40 \\
\hline & $\begin{array}{l}\text { c. Pengolahan bahan baku enceng gondok menjadi } \\
\text { tas/ kerajinan tangan cantik }\end{array}$ & 40 \\
\hline \multirow{2}{*}{$\begin{array}{l}\text { Tidak mengetahui } \\
\text { kualitas produksi yang } \\
\text { layak dijual dan berdaya } \\
\text { saing tinggi }\end{array}$} & $\begin{array}{l}\text { a. Kualitas bahan baku dan teknik produksi } \\
\text { yang bernilai seni }\end{array}$ & 40 \\
\hline & $\begin{array}{l}\text { b. Koordinasi dengan } \mathrm{R} \& \mathrm{D} \text { craft sebagai mitra } \\
\text { kedua untuk membantu pemasaran produk }\end{array}$ & 40 \\
\hline
\end{tabular}

Sumber : Data Penelitian diolah

b. Realisasi Metode yang ditawarkan

1. Metode pendekatan yang ditawarkan untuk mendukung realisasi IbM.

c. Diskripsi Kegiatan

Kegiatan ini melalui 3 (tiga) tahapan yang merupakan satu kesatuan rangkaian kegiatan yaitu:

1) Relationship I : Introduction Mencakup penjelasan konsep dasar untuk membuat kerajinan berbahan dasar enceng gondok.

2) Relationship 2: Perencanaan Penilaian aspek potensi yang dikembangkan dan kemampuan pemuda pemudi karang taruna dengan prinsip non cost dan low cost, kegiatan ini meliputi:

a) Penyusunan alat kegiatan sampai menghasilkan 
kerajinan tangan

b) Menghitung biaya produksi kerajinan berdasar biaya keseluruhan.

c) Penyusunan alternatif pemecahan biaya produksi dalam gambar alternative

d) Penyusunan rencana aksi atas keputusan pemuda pemudi karang taruna dan UMKM

e) Menumbuhkan komitmen UMKM/ pemuda pemudi karang taruna yang didampingi untuk explorasi masyarakat ekonomi kreatif.

3) Relationship 3: Implementasi Proses akhir penambangan dengan meningkatkan kinerja usaha dan produksi yang dapat mendatangkan keuntungan baik secara ekonomi dan lingkungan.

\section{b). Tahapan kegiatan kontinum relationship}

Relationship yang akan dilaksanakan meliputi 3 kegiatan utama yakni (1)

Sosialisasi (2). Kontinum relationship

(3) Tehnical meeting.

1).Sosialisasi dilakukan dua kali dengan materi, 1). Peilatihan konsep pembuatan kerajinan dari bahan enceng gondok; 2). Pemanfaatan limbah enceng gondok dengan konsep masyarakat ekonomi kreatif serta memecahkan persoalan secara tuntas (Action learning set).

2). Kontinum relationship berbentuk pendampingan komprehensif ( technical assistance), dilakukan untuk membantu pemuda - pemudi karang taruna desa Kemlagi lor bersinergi bersama UMKM sehingga mereka mampu mengidentifikasi proses produksi, melakukan perhitungan biaya dan menyusun alternative perbaikan dan memutuskan rencana aksi untuk menyelesaikan masalah tersebut.

3) Tehnical meeting dilakukan 2 kali dengan maksud informasi dengan evaluasi kemajuan kegiatan tim pelaksana dan UMKM sehingga menerima penyempurnaan keberhasilan kegiatan dimasing masing kelompok karang taruna. Kegiatan net work meeting dilakukan dua kali dimaksudkan untuk informasi dan mensinergikan kegiatan dengan para steakholder ( pemerintah desa).

\section{c). Partisipasi Mitra}

Mitra I; adalah pemuda - pemudi karang taruna Desa Kemlagi Lor yang merupakan gabungan dari 5 dusun di desa Kemlagi Lor, Mitra I (pertama) sebagai obyek pelatihan yang difokuskan pada pola motivasi dan ketrampilan serta keahlian pembuatan produk kerajinan.

Mitra II; adalah R \& D craft sebagai tenaga pemasaran produk yang dihasilkan oleh mitra pertama, dengan pola hubungan yang komprehensif ini produk yang dihasilkan oleh kelompok karang taruna dapat dijual.

\section{d). Evaluasi Program}

Kegiatan IbM di desa Kemlagi Lor berjalan selama dua belas (12) bulan dengan luaran produk kerajinan enceng gondok dan motivasi entrepreneur, selanjutkan akan 
dilakukan pendaftaran unit usaha ke dinas perindustria, perdagangan dan koperasi kabupaten Lamongan dan akan mendapatkan pembinaan secara berkala dari dinas terkait baik peningkatan sumberdaya manusia dan permodalan

\section{HASIL PENELITIAN DAN PEMBAHASAN}

Hasil yang dicapai dalam kegiatan pengabdian pemberdayaan dan pendampingan adalah sebagai berikut:

1). Kegiatan surve awal dan penerapan pelaksanaan pelatihan yaitu mulai dari perizinan, sosialisasi dan pelaksanaan pengolahan limbah enceng gondok dalam usaha pengentasan kemiskinan. Pada awal pertemuan survey ke lokasi mitra dengan meminta data karang taruna, melihat potensi bahan baku dan koordinasi dengan kepala desa sampai dengan kecamatan. Dari hasil wawancara dan survey lokasi enceng gondok yang melimpah mengganggu aktivitas aliran sungai sehingga setiap tahun tiap desa menghabiskan dana sekitar Rp. 25.000.000 (dua puluh lima juta rupiah), untuk proses pembenahan. Melihat fenomena pemuda karang taruna yang berpotensi terhadap kerajinan dan kapabel terhadap nilai inovatif. Maka pemberdayaan ini layak dilaksanakan anyaman enceng gondok sangat bernilai jual tinggi sebagai bahan baku kerajinan tangan ( handycraft). Di antara produk yang bisa di inovasi dari bahan enceng gondok adalah, meubeler, tas sampai anyaman untuk daun pintu.

2). Audiensi dengan pejabat setempat, bapak camat, kepala desa serta pihak R \& D selaku fasilitator sangat lancar, mengingat antusias warga terhadap program ini memuaskan.

Pada hakekatnya program pemberdayaan yang kami laksanakan adalah komprehensif melalui kontinum relationship yaitu pemberdayaan, pelatihan dan pendampingan. Keutuhab program tercapai ketika melakukan satu persatu proses langkah yang kami buat secara konsisten. Dari hasil audiensi dengan pejabat setempat mulai dilakukan panen enceng gondok di sekitar sungai dan parit yang ukurannya tinggi $70 \mathrm{Cm}$

Hasil penggolongan bahan baku sebagai proses awal selesai kemudian dilakukan tahap pengeringan dengan waktu 20 hari, dan selanjutnya kemasan pelatihan terpadu, yaitu:

1). Pelaksanaan pendampingan kontinum relationship

a) Pembersihan aliran sungai dibantu oleh seluruh steakholder yang terlibat, mulai warga, aparat dan mahasiswa.

b) Pemenuhan bahan baku enceng gondok yang potensi untuk produksi yaitu diantaranya enceng gondok ukuran $70 \mathrm{~cm}$ dengan tangkai yang bagus, sehigga berkualitas.

c) Bahan baku yang kering dilakukan pelintiran atau ada sebagian yang bisa di tenun, keuntungan dari pemilihan lokasi desa kemlagi lor Kecamatan turi adalah masyarakat Turi sudah populer dengan anyaman dan tenunan

d) Proses pembuat anyaman yaitu keterlibatan 2 mitra dalam pemberdayaan, Proses 
pembuatan enceng gondok dimulai dari penjelasan TIM R \& D craft tentang macam produk yang bisa dilakukan dari bahan dasar enceng gondok diantaranya tas, dompet, tempat tissu dan wacana baru bisa sebagai pemasok bahan baku untuk dijual ke perusahaan forniture.
Raimond, C. Grant Milles, Colla borativen (2015) Entrepreneursthip A Business model for Continous Innovation for Creative economic, Organizational Dynamic Vol 35 No 1 pp $1-11$.

Zarnowitz, Victor ( 2014), Business Cycle analysis and Expectational survey Datan NBER Working paper, 2010

\section{KESIMPULAN DAN SARAN}

Pemberdayaan sistem kontinum relationship menguntungkan pihak mitra karena sangat menguntungkan mitra sebagai usaha pemula. Aspek marketing yang ditakutkan oleh pengusaha pemula dapat diatasi ketika mitra kedua sebagai pemateri sekaligus sebagai market dengan gandeng renteng sesama pengusaha. Aspek manajemen selanjutnya dilakukan guna menunjang keberlanjutan program kearah kesuksesan usaha yang sedang dirintis.

\section{DAFTAR PUSTAKA}

Aronson, D, Bostic, R Huck, P Rownsed. R. 2014 Continum Relationship and Small Business Use. Of Market, J. Urban econ 55.46-67

Beck, Thorsten and Levine Ross. (2014) “ New Firm Formation and Industry Growth; Daes Having a Market", University of Minnesota. Mimeo.

Gaglin, C.M Karz.J.A (2014)" The Psychological basis of opportunity Identification Entrepreneurial element Hand Loom Product. Small Business economics, 16 (2) 95- 111. Grandi A Grimaldir ( 2015) Exploring the net work characteristic of new venture faunding terms craft Industry. Small business economics 21 (4) 329-341. 